\title{
How Market Orientation Induces Small Businesses' Performance: The Role of Strategic Fits
}

\author{
$a^{*}$ Quang-Huy Ngo \\ Can Tho University of Technology, Vietnam
}

\begin{abstract}
This study draws from the contingency theory and the resource-based view to propose that the prospector strategy mediates the link between market orientation and small businesses' performance. Data were collected from 161 small businesses located in Vietnam and PLS-SEM was used to assess the research's framework. The results reveal that the prospector strategy fully mediates the link between market orientation and the performance of small businesses located in Vietnam. This study suggests that the owners should follow the prospector strategy when their small businesses follow market-oriented approaches to find the performance implications of their businesses. This study contributes to the strategic management literature by showing that the prospector strategy must be considered when assessing the positive effects of market orientation on performance. This study also overcomes the prior strategic management studies' limitations relating to the proposals of the analytic framework to assess strategic fits by using the Cartesian contingency framework. Lastly, this study advances our knowledge of the contingency theory in the context of small businesses. The results should be interpreted with due concern for the generalized issues, lack of a pilot test, and low response rate.
\end{abstract}

Keywords: market orientation, performance, prospector strategy, small business, strategic fits, Vietnam.

JEL Classification: M1 


\section{Introduction}

Small businesses have their advantages, which other types of businesses may not have. For example, the advantage of size permits these businesses to have a high degree of flexibility and a close relationship with their customers (Nooteboom, 1994). This advantage allows this type of business to quickly change and adapt to its customers' tastes and provide products/services to meet their needs (Ebben and Johnson, 2005). When an organization commits to the continuous delivery of superior values to its customers, this organization is driven by the market's orientation, and a marketing philosophy (Slater and Narver, 1994b). It is argued that small businesses can find performance implications when orienting themselves to the market (Appiah-Adu, 1998, p. 20).

There are two explanations for the positive impact of market orientation on performance. First, based on the resource-based view (Barney, 1991), Lim et al., (2017) and Morgan et al., (2009) proposed that market orientation refers to intangible assets, which allows businesses to gain competitive advantages by improving their performance. Second, it is argued that this relationship is contingent (Kiessling et al., 2016). In the strategic management literature, the contingency theory proposes that strategic choices need to fit with the contingency factors to foster performance implications (Venkatraman and Camillus, 1984).

Empirical evidence reveals that when organizations are driven by the market's orientation, adopting innovation strategies is crucial for performance implication (Newman et al., 2016). In the strategic literature, the prospector strategy is suggested as it allows organizations to improve their per- formance by focusing on innovation (Miles and Snow, 1978). This strategy is argued to be an innovation-oriented strategy (Song et al., 2016). In the context of small businesses, this strategic framework is argued to be more relevant than other strategic frameworks (Gimenez, 2000; Ibrahim, 1993). An empirical finding (see Grimmer et al., 2018; Song et al., 2016) successfully established the link between this type of strategy and the performance of small businesses. For this, it is expected that the fit between the prospector strategy and the market's orientation induces higher levels of performance in small businesses.

Surprisingly, there is no empirical evidence showing that the strategic fit between the prospector strategy and the market's orientation permits small businesses to perform better. Besides, most of the strategic management literature studies tend to focus on large businesses (see Chung et al., 2012; Pertusa-Ortega et al., 2010; Wu et al., 2014). As a consequence, it hampers the advancement of strategic management literature for small businesses.

Thus, this study aims to gain an insight into small businesses in Vietnam. The Vietnamese context provides an excellent setting for this research because of the following reasons. First, more than $97 \%$ of businesses are small and medium enterprises (see Koushan, 2017). Thus, research into small businesses is appropriate. Second, due to the lack of attention given to the Vietnamese context, the knowledge of strategic choices seems to be limited in the Vietnamese context. It challenges the relevance of the theory, which was previously tested in different locations. These two reasons motivated this study to focus on Vietnam. Drawing from the contingency theory and the resource-based view, this study 
proposes a research framework, which indicates the influencial role of the prospector strategy on the link between the market's orientation and the performance of small businesses. The results show that this strategy mediates the link between market orientation and the performance of small businesses.

In light of the findings, this study's results contribute to the contingency-based studies. First, this study shows that the strategic fit is represented by the full mediating effects of the prospector strategy on the link between market orientation and small businesses' performance. In the strategic literature, market orientation is demonstrated to induce performance (Gruber-Muecke and Hofer, 2015; Migliori et al., 2019; Tsiotsou and Vlachopoulou, 2011; Vega-Vázquez et al., 2016). However, the empirical evidence is mixed (Gaur et al., 2011, p. 1187). According to the contingency theory, strategic choices influence the degree to which the contingency factors (the market's orientation), induce performance. Consistently, this study reveals that small businesses cannot find performance implications because of the market's orientation. Rather than these, businesses need to select an appropriate strategy, such as the prospector strategy, to fit the market's orientation and to find the performance implications they seek. In this regard, this study contributes to the literature by emphasizing the crucial role of the prospector strategy on the link between the market's orientation and performance.

Second, this study also overcomes the limitation relating to the formulate analytical model to assess strategic fits. Notably, contingency-based research has been criticized due to its ambiguity in formulating contingency hypotheses (Boyd et al., 2012). The focal point of contingency-based research is to gain insights into how the fit between the contingency factors and strategy induces performance. However, there is no unique way to frame such types of fit. It is posited that there are various forms of fit, and each form needs to be assessed by a particular analytic framework (see Venkatraman, 1989). As a result, the mismatch between the form of the fit and the analytical framework used to assess this form may lead to problematic interpretations of the results (Hitt et al., 2004). This hampers gaining any insights into the application of the contingency theory in strategic management's research (Galbraith and $\mathrm{Na}$ thanson, 1978). This study overcomes such limitations because it considers the mediating form of the fit to explain the fit between a contingency variable and the strategy which improves small businesses' performance. Besides, by examining the mediating form of the fit, this study also enriches the mediating form of the fit in contingency-based studies due to the small numbers of studies investigating the mediating effects in research into strategic management (Boyd et al., 2012).

Third, this study also sheds more light on contingency-based studies by focusing on the context of small businesses. More specifically, the organization's contingency theory illustrates that organizations must develop strategies which fit with their operating environments (e.g., contingency factors) (Donaldson, 2001). It is based on the notion that there is no universal strategy that allows organizations to achieve their optimum performance (Venkatraman and Camillus, 1984). However, the use of this theory to explain this fit can mostly be found in studies into large organizations (see Chung et al., 2012; Pertusa-Ortega et al., 2010; Wu et al., 2014), while there has been a lack of attention paid to small businesses. Hence, this study overcomes the limitations by situating itself in 
the context of small businesses in Vietnam. In such a way, this paper contributes to the growth in strategic management's use of the contingency theory in the context of small businesses (see Raymond and St-Pierre, 2013; Taylor and Taylor, 2014).

The outline of this paper is formulated as follows. The next section reveals the literature review and develops the hypotheses. The study's methods are introduced later. The next two sections detail the results and discussion of the paper. The last section indicates the conclusion and limitations of this paper.

\section{Literature Review}

\section{Strategic Choices}

Miles and Snow (1978) indicated that four types of strategies, including the prospector, defender, analyzer, and reactor, drive organizational behavior. Most studies investigate organizational strategy along the continuum between the defending and prospecting strategies. First of all, the prospector strategy drives organizations to provide products or services that meet customers' demands by enhancing their experiences with the products and services provided. On the other hand, defenders emphasize the low cost while providing products and services of a high quality. This strategy allows organizations to defend their market share through improvements in their operational efficiency. The analyzing strategy is a hybrid strategy, a combination of the prospector's and defender's strategies (Kald et al., 2000). The last strategy type is the reactor strategy. This is thought of as being no proper strategy because the organizations that use this show clueless strategic behavior and only react to changing market environments.

\section{Market Orientation}

In the eighties, two different approaches were attempted to conceptualize market orientation. The first approach suggested that this variable describes organizational behavior. Notably, Kohli and Jaworski (1990) defined it as "the organization-wide information generation and dissemination, and appropriate response related to current and future customer needs and preferences." The second approach considered this variable as a cultural variable. In a specific way, Narver and Slater (1990) conceptualized this variable as "the organization's culture that most effectively and efficiently creates the necessary behavior for the creation of superior value for buyers and, thus, continuous superior performance for the business." Although these are two different approaches, they both share a similarity, because this culture drives organizational behavior to acquire more information about the customers and competitors in the market and disseminate such information throughout the organization's business.

\section{Research Framework}

This study draws upon the resource-based view and the contingency theory to propose the research model (see Figure 1). Prior studies (Lim et al., 2017; Morgan et al., 2009) posit that the direct relationship between market orientation and performance can be explained based on the resource-based view (Barney, 1991). According to the resource-based theory, an enriched organizational resource induces improved performance (Penrose and Penrose, 2009). As a result, the attainment of a competitive advantage requires organizational resources to be rare and valuable (Wernerfelt, 1984). 
$\mathrm{H} 4$

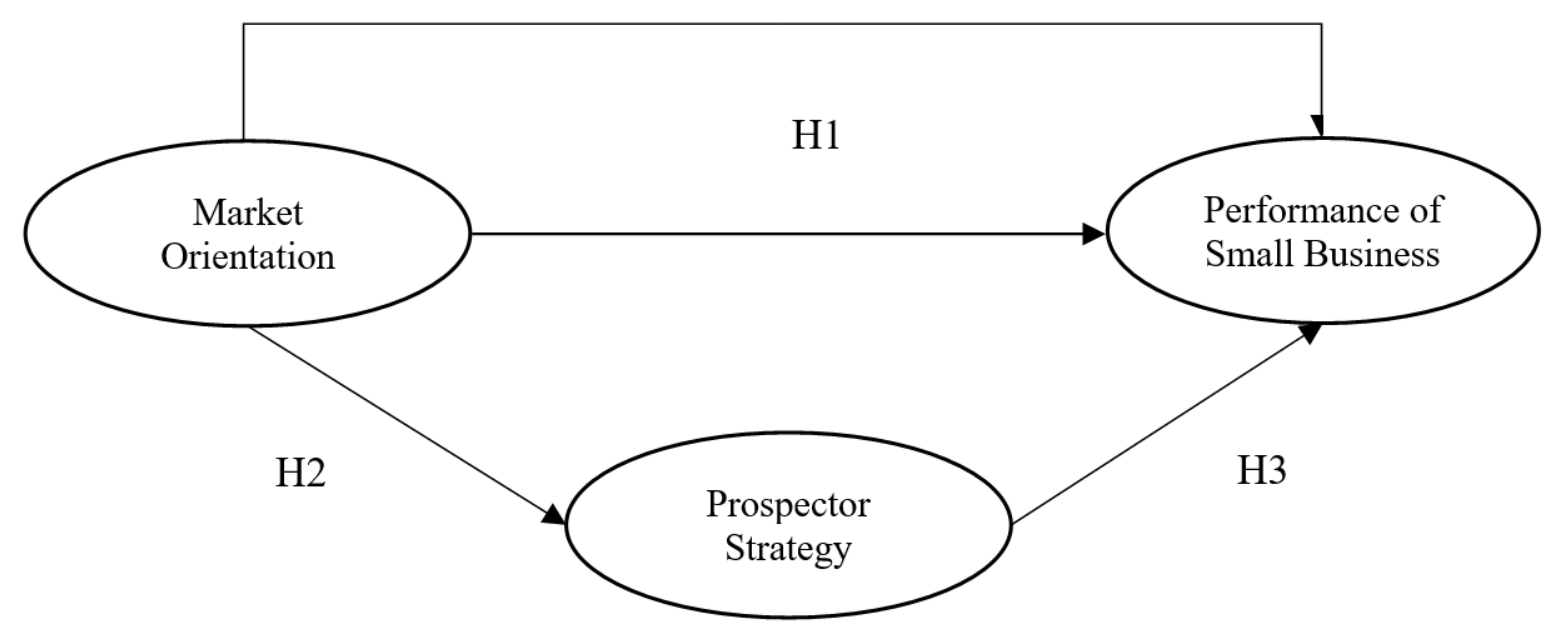

Figure 1. Proposed Research Model

Furthermore, sustainable performance requires this resource to be difficult for other organizations to imitate (Dierickx and Cool, 1989). Thus, based on this view, the market's orientation is an intangible asset, which allows enhanced performance.

The contingency theory posits that there is no universal way to design organizations that can foster performance implication. In this regard, contingency-based studies of strategic management argue that an organizational strategy needs to fit with the contingency factors to improve performance. The organizational culture is an important contingency variable (Chen et al., 2018; Yarbrough et al., 2011). Narver and Slater (1990) suggest that the market's orientation is an organizational culture. Thus, based on this theory, market orientation is the organizational culture, which needs to fit with the strategic choice, to improve performance.

It is argued that market orientation drives organizations to adopt innovative strategies to improve their performance
(Newman et al., 2016). Since only prospectors are expected to have a high degree of innovation, in comparison to others (Aragón-Sánchez and Sánchez-Marín, 2005), the fit between the market's orientation and the prospector strategy allows small businesses to find performance implication. To establish the fit, this study relies on the analytical framework of Venkatraman (1989), which indicates that the mediating effects of strategy affect the relationship between the contingency factor and performance. This framework has a high degree of reliability because it gained a great deal of attention from strategic management theorists (see Boyd et al., 2012; Hitt et al., 2004).

\section{The Link between Market Orientation and the Performance of Small Busi-} nesses

Market orientation may induce organizational performance as follows: thanks to the benefits of greater market orientation, organizations gain insights into the customers' chain of values, and the strategic capabil- 
ities encompassing their future actions $(\mathrm{Oz}-$ kaya et al., 2015; Singh and Ranchhod, 2004). Hence, the most productive organizational resources are easily selected to match the current market conditions (Slater and Narver, 1994a). In this way, resource-based theorists consider the market's orientation as an intangible organizational resource, which allows the organizations to make performance improvements (Morgan et al., 2009). For this argument, the previous studies' results show a positive relationship between market orientation and performance (Gruber-Muecke and Hofer, 2015; Migliori et al., 2019; Tsiotsou and Vlachopoulou, 2011; Vega-Vázquez et al., 2016). Hence, this paper expects similar effects describing the positive relationship between market orientation and the business units' performance.

H1: There is a positive relationship between market orientation and the performance of small businesses.

\section{The Link between Market Orientation and the Prospector Strategy}

One possible reason explaining the positive relationship between market orientation and the prospector strategy is the emphasis on innovation. Particularly, market orientation leads to a focus on customers and competitors (Kohli and Jaworski, 1990). A focus on customers provides an insight into their demands relating to products/services. Innovation is crucial for small and medium businesses to deliver products/services which satisfy their customers' demands, which in turn gains them competitive advantages when they focus on their customers (Domi et al., 2020). Besides, a focus on competitors induces an in-depth understanding of them. Small and medium businesses can gain competitive advantages through innovation (e.g., product innovation allows the introduction of new products/service ahead of their competitors, to maintain and win market share) when they focus on their competitors (O'Dwyer and Gilmore, 2019). In this regard, it is posited that market orientation requires an innovative strategy to find competitive advantages (Newman et al., 2016). The prospector strategy allows small businesses to find methods to enhance their innovations (Kickul and Gundry, 2002). Therefore, it is expected that a high degree of market orientation leads to the prospector strategy. Thus, the second hypothesis was proposed as follows.

H2: There is a positive relationship between market orientation and prospector strategy.

\section{The Link between the Prospector Strategy and the Performance of Small Businesses}

Miles and Snow (1978) argued that the prospector strategy is positively associated with high performance. Thanks to some unique characteristics, the prospector strategy allows for a greater competitive advantage. Parnell (2013) argued that small businesses which choose to use the prospector strategy are more likely to commit to the most updated technology, and their managers always search for new approaches to gain efficiency and effectiveness. It is argued this technology allows small businesses to gain first-mover advantages resulting from the differences in the technology used (Lowe and Atkins, 1994). First movers are suggested to have superior performance due to the market's lack of competition (Lieberman and Montgomery, 1988). As a result, small businesses using the prospector strategy can enjoy superior performance due to the selection of that strategy. Empirical evidence strongly supports the performance implications of 
small businesses choosing to use the prospector strategy (Grimmer et al., 2018; Song et al., 2016). Thus, this paper proposes the third hypothesis as follows.

H3: There is a positive relationship between thee prospector strategy and the performance of small businesses

\section{The Mediating Effects of the Prospec- tor Strategy}

It is argued that performance implications can be found when there is a fit between the contingency factors and strategic choices (Chandler, 1962; Donaldson, 2001). There are various forms of fit. One of the forms can be represented by the mediating effects of the strategic choices that have been made (Boyd et al., 2012; Hitt et al., 2004). According to the analytical framework from Venkatraman (1989), when strategic choices act as mediators of the link between the contingency variables and performance, the mediated form of fit is established. Some empirical studies use this framework to assess the mediated form of fit between the contextual variables and performance (Chow et al., 2013; Edelman et al., 2005). Similarly, this study also uses this framework to assess the mediated form of fit, which represents that the link between market orientation and small businesses' performance is mediated by the prospector strategy.

Market orientation allows small businesses to gain competitive advantages through innovation (see Bamfo and Kraa, 2019; Leal-Rodríguez and Albort-Morant, 2016; Yadav et al., 2019). In this regard, small businesses need to select the appropriate strategy, which relates to innovation, to gain improved performance. The prospector strategy is suggested to be an innovation-oriented strategy
(Song et al., 2016). Thus, it is expected that the fit between market orientation and the prospector strategy allows small businesses to improve their performance. Based on the analytic framework mentioned previously, the fit represents the mediating effects of the prospector strategy on the link between market orientation and performance. This proposition is consistent with the prior studies, which revealed this relationship is mediated by innovation in the context of small and medium businesses (Bamfo and Kraa, 2019; Leal-Rodríguez and Albort-Morant, 2016; Yadav et al., 2019). The last hypothesis is proposed as follows.

H4: There is a mediating effect of the prospector strategy on the link between market orientation and the performance of small businesses.

\section{Methods}

\section{Sampling and data collection}

This study used a convenience sampling method to collect the data. This study focused on small businesses located in the city of Can Tho, which is one of the biggest cities in the Mekong Delta of Vietnam. There were some criteria which this study took into account before sending it . First, the targeted respondents were small business owners because it was more likely that the owner knows his/her business's strategy. Second, this study also focused on businesses operating in the service and trade sectors, which employed less than 50 employees because of the definitions in Vietnamese regulations (see 39/2018/ND-CP, 2018). Third, and similar to a strategic study (see Appiah-Adu and Blankson, 1998), this study only examined the businesses which had operated for more than three years because these 
businesses were more likely to have a primary strategy. These criteria were similar to the criteria used for the data's selection in prior studies, which had examined market orientation (see Appiah-Adu, 1998; Appiah-Adu and Blankson, 1998) and the prospector strategy (see Grimmer et al., 2018; Kickul and Gundry, 2002; Song et al., 2016) in the context of small businesses.

The data collection included two phrases. In the first phase, this study took advantage of networking. Remarkably, the collection process was assisted by a staff member who works for the Can Tho authority. This person had a list of e-mail addresses of small businesses located in Can Tho. However, this person agreed to help by only sending an e-mail to those small businesses. Therefore, an e-mail was sent to this person's e-mail address. This e-mail included a summary of the study and the link to access the online survey. Next, the person forwarded this e-mail to those aforementioned businesses. After three months, the online survey showed that there were 173 returned surveys. Of this number, there were 161 useable surveys, due to some of them missing values and some that were sent to the wrong targeted respondents (e.g., the respondents were not the owners of the businesses).

The data collection process suggested that this study should use convenience sampling. This is similar to Bamfo and Kraa (2019), who used it to examine the relationship between the market's orientation and the performance of small and medium businesses. Thus, this sampling was appropriate for this study. Besides, the purpose of this study is to draw upon the resource-based view and the contingency theory to propose a research model. It is argued that when the main goal is to examine the relevance of the theories used to predict the relationships, rather than generalize to a larger population, convenience sampling is appropriate (see Speklé and Widener, 2018, pp. 4-5).

\section{Measures}

\section{Market Orientation (MO)}

This study adopted an instrument from Cravens and Guilding (1999) to measure the degree to which small businesses orientate themselves to the market. One reason for this adoption was that Cravens and Guilding (1999) drew from the work of Narver and Slater (1990), which suggested market orientation was a form of organizational culture to operationalize this instrument. It was appropriate because this study considered market orientation to be a cultural factor, which needed to fit with MAS design to improve performance.

In this instrument, there are four statements. This instrument has previously been used in earlier studies to assess the degree of the market's orientation (Cadez and Guilding, 2008, 2012; Guilding and McManus, 2002), and as such, it is known to possess high reliability. A 5-point Likert scale ranging from "Highly disagree" (1) to "Highly agree" (5) was used to measure the degree to which respondents agree with the statements.

\section{Prospector Strategy (PS)}

Moore (2005) provided a reliable instrument, which was adopted by this study to measure the degree to which small businesses follow the prospector strategy. This instrument was operationalized based on the theoretical framework of Miles and Snow 
(1978). There are eight items in this instrument. This instrument was originally used to assess the degree to which a retailer follows the prospector strategy. Hence, some minor revisions were made to ensure its proper use in the context of small businesses. This instrument asks respondents to indicate their agreement with their business's behavior. A 5-point Likert scale ranging from "Highly disagree" (1) to "Highly agree" (5) was used to measure this instrument.

\section{Performance of Small Businesses (PER)}

Due to the difficulty in obtaining the objective measures as ROA and ROS, this study used the subjective measure to assess small businesses' performance. As mentioned above, this study benefited from networking. It was suggested that the owners were less likely to rate these financial indicators of their businesses in the survey. In the same vein, the study of Acquaah (2007) also suggested the same difficulties during data collection in emerging countries. Besides, measuring small businesses' performance by using such financial indicators does not properly reflect the actual performance. The owners of small businesses consider non-financial and financial indicators to be equally important for their businesses' performance, because they emphasize the attainment of not only the businesses' profitability but also its goals (Jarvis et al., 2000).

A modified instrument, adopted from Cadez and Guilding (2008), was used to assess the performance of small businesses. This instrument required the respondents to rate their businesses' performance regarding the attainment of the businesses' goals. A 5-point Likert scale ranging from "Well-be- low average" (1) to "Well-above average" (5) was used to measure this instrument.

\section{Assessment of Common Method Bias}

This study collected all the measures in the same survey. As a result, it may be subject to common method bias. This study used two approaches to examine whether or not common bias existed within the data. First, this study assessed Harman's single-factor test (Podsakoff and Organ, 1986). The results showed that one single factor explained $27.732 \%$ of the total variance. Thus, there was no factor accounting for the majority of the covariance among the measures.

The second approach used a marker variable (MV) to assess the common method bias (Lindell and Whitney, 2001). In this study, the marker variable was used to assess the degree of perceived usefulness from travelling by the respondents, which theoretically had no relationship with the other variables in the research's framework. The results indicated no correlation between this marker variable and the other main variables. To sum up, this study has no concerns about common method bias.

\section{Statistical Analysis}

This study used the structural equation modeling (SEM) technique, estimated from partial least squares (PLS), to test the hypotheses. PLS-SEM allows for the estimation of partial model structures, defined in a path model, by combining the principal components of the analysis and ordinary least squares regressions (Mateos-Aparicio, 2011). This technique was believed to be highly reliable for strategic management research (Hair et al., 2012). Besides, this technique 
Gadjah Mada International Journal of Business - January-April, Vol. 23, No. 1, 2021

also gained much attention from researchers because it can handle small sample sizes and any non-normality in the data (Cassel et al., 1999; Hair et al., 2017).

\section{Results}

\section{Assessment of the Constructs' Unidi- mensionality}

This paper examined the constructs' unidimensionality by conducting a principal that three factors corresponded to the intended measuring items, except for the following items: PER_1, PER_3, and PS_5 (see Table 1). Thus, these items were removed, and the above test was re-run. The results indicated that these were the three factors corresponding to the remaining items.

\section{Assessment of Measurement Models}

In this stage, the study assessed the convergent validity, discriminant validity, the internal consistency of items of the con-

Table 1. Exploratory Factor Analysis

\begin{tabular}{|c|c|c|c|c|c|}
\hline \multirow[t]{2}{*}{ Constructs } & \multirow[t]{2}{*}{ Items } & \multicolumn{2}{|c|}{ 1st run } & \multicolumn{2}{|c|}{ 2nd run } \\
\hline & & Loadings & Eigenvalues & Loadings & Eigenvalues \\
\hline \multirow[t]{5}{*}{$\mathrm{MO}$} & & & 2.077 & & 2.017 \\
\hline & MO_1 & 0.686 & & 0.715 & \\
\hline & MO_2 & 0.670 & & 0.678 & \\
\hline & MO_3 & 0.809 & & 0.755 & \\
\hline & MO_4 & 0.568 & & 0.594 & \\
\hline \multirow[t]{7}{*}{ PS } & & & 2.741 & & 4.206 \\
\hline & PS_1 & 0.722 & & 0.712 & \\
\hline & PS_2 & 0.683 & & 0.731 & \\
\hline & PS_3 & 0.752 & & 0.724 & \\
\hline & PS_4 & 0.616 & & 0.602 & \\
\hline & PS_5 & 0.482 & & removed & \\
\hline & PS_6 & 0.775 & & 0.792 & \\
\hline \multirow[t]{8}{*}{ PER } & & & 4.714 & & 2.273 \\
\hline & PER_1 & 0.665 & & removed & \\
\hline & PER_2 & 0.602 & & 0.625 & \\
\hline & PER_3 & 0.430 & & removed & \\
\hline & PER_4 & 0.724 & & 0.745 & \\
\hline & PER_5 & 0.732 & & 0.731 & \\
\hline & PER_6 & 0.622 & & 0.614 & \\
\hline & PER_7 & 0.780 & & 0.761 & \\
\hline
\end{tabular}

axis factoring with Oblimin rotations (see Fabrigar et al., 1999). The results indicated structs and also examined the multicollinearity among these items. The establishment of 
convergent validity required the the following conditions to be satisfied (Fornell and Larcker, 1981). It required the average variance extracted (AVE) to be higher than the threshold value of 0.5 . The second one was indicated the establishment of discriminant validity (Henseler et al., 2015). Table 3 shows the establishment of discriminant validity because this condition was satisfied.

Table 2. Cross-loadings and VIFs of Items

\begin{tabular}{ccccc}
\hline & MO & PER & PS & VIF \\
\hline MO_1 & $\mathbf{0 . 8 0 3}$ & 0.146 & 0.249 & 1.639 \\
MO_2 & $\mathbf{0 . 7 7 5}$ & 0.176 & 0.192 & 1.535 \\
MO_3 & $\mathbf{0 . 7 9 6}$ & 0.194 & 0.163 & 1.701 \\
MO_4 & $\mathbf{0 . 7 3 6}$ & 0.131 & 0.210 & 1.423 \\
PER_2 & 0.125 & $\mathbf{0 . 6 6 4}$ & 0.115 & 1.465 \\
PER_4 & 0.136 & $\mathbf{0 . 8 0 5}$ & 0.239 & 1.865 \\
PER_5 & 0.183 & $\mathbf{0 . 8 0 1}$ & 0.210 & 1.771 \\
PER_6 & 0.189 & $\mathbf{0 . 7 7 9}$ & 0.251 & 1.537 \\
PER_7 & 0.147 & $\mathbf{0 . 7 7 2}$ & 0.164 & 1.844 \\
PS_1 & 0.202 & 0.170 & $\mathbf{0 . 7 6 7}$ & 1.751 \\
PS_2 & 0.113 & 0.254 & $\mathbf{0 . 7 6 0}$ & 1.814 \\
PS_3 & 0.168 & 0.206 & $\mathbf{0 . 7 7 1}$ & 1.756 \\
PS_4 & 0.295 & 0.219 & $\mathbf{0 . 7 7 9}$ & 1.578 \\
PS_6 & 0.213 & 0.190 & $\mathbf{0 . 8 2 2}$ & 2.101 \\
\hline
\end{tabular}

satisfied when each item's outer loading on its respective construct was higher than the other cross-loadings on that construct. Also, a crucial notion was that these loadings were
The internal consistency of the constructs was valid as the composite reliability scores and Cronbach's alpha value were both higher than the 0.70 threshold value (Hair et

Table 3. Cronbach's Alpha, Composite Reliability, AVE, and HTMT

\begin{tabular}{ccccccc}
\hline & $\begin{array}{c}\text { Cronbach's } \\
\text { Alpha }\end{array}$ & $\begin{array}{c}\text { Composite } \\
\text { Reliability }\end{array}$ & AVE & & \multicolumn{3}{c}{ HTMT } \\
\cline { 5 - 7 } & 0.783 & 0.86 & 0.605 & MO & PER & PS \\
\hline MO & 0.826 & 0.876 & 0.587 & 0.253 & - & - \\
PER & 0.840 & 0.886 & 0.609 & 0.311 & 0.306 & - \\
PS & & & & & & - \\
\hline
\end{tabular}

necessarily higher than 0.5 . Table 2 and Table 3 reveal that convergent validity was satisfied.

Next, assessing discriminant validity required the examination of the heterotrait-monotrait (HTMT) ratios of the correlation (Henseler et al., 2015). If these values were less than the threshold value of 0.85 , it al., 2011). Table 3 indicates that these values were all higher than 0.7 . Thus, it suggests the establishment of internal consistency.

Assessing the multicollinearity between items required the examination of the item's VIFs . If these values for each item were less than the threshold value of five, then that 
Gadjah Mada International Journal of Business - January-April, Vol. 23, No. 1, 2021

satisfied the condition, so there was no multicollinearity (Hair et al., 2011). Table 2 indicates the absence of multicollinearity among the measured items.

\section{Structural Model}

This study followed the suggestion by Hair et al., (2011) to assess the structural model using PLS-SEM. Notably, the assessment should be examined by using the bootstrapping procedure with 5,000 replacements.

There were some crucial notions that multicollinearity between the latent variables, the predictive validity of the parameter estimates, and the predictive power should be satisfaction of the three criteria allowed the interpretation of the results of the hypotheses' paths. Therefore, these results suggested it was safe to interpret the results of the structural model.

The results revealed that market orientation is positively correlated with the prospector strategy $(\beta=0.263, p=0.001)$. It was also indicated that the link between the prospector strategy and small businesses' performance was significant $(\beta=0.228, p=0.005)$. However, at variance with the proposal, market orientation was insignificantly related to the performance of small businesses $(\beta=0.174$, $p=0.074)$. Therefore, the data only supported hypotheses $\mathrm{H} 2$ and $\mathrm{H} 3$.

Table 4. $\mathrm{R}^{2}, \mathrm{Q}^{2}$, and VIFs between Constructs

\begin{tabular}{cccccc}
\hline & $\mathbf{R}^{2}$ & $\mathbf{Q}^{2}$ & \multicolumn{3}{c}{ VIFs } \\
\cline { 4 - 6 } & & & MO & PER & PS \\
\hline MO & - & - & - & 1.074 & 1.000 \\
PERF & 0.091 & 0.044 & - & - & - \\
PS & 0.069 & 0.036 & - & 1.074 & - \\
\hline
\end{tabular}

assessed before interpreting the structural model's results. First, and similar to the multicollinearity assessment between items, the validity of this requires the VIFs to be less than the threshold value of five (Hair et al., 2011). Table 4 shows that the VIFs were less than five, which suggested the absence of multicollinearity between the constructs. Second, the parameter estimates' predictive validity was established by assessing the Stone-Geisser $\mathrm{Q}^{2}$ value (Geisser, 1974; Stone, 1974). It was suggested that $Q^{2}$ values should all be larger than zero to ensure validity (Chin, 1998; Hair et al., 2011). Table 4 shows the establishment of the predictive validity of the parameter's estimates. Third, this study assessed the predictive power of the path by examining the $R^{2}$ values. Table 4 indicates a sufficient degree in the $\mathrm{R}^{2}$ values. In total, the
Because Hypothesis $\mathrm{H} 4$ required the assessment of mediating effects, this study followed the procedure described by Zhao et al., (2010). This study also used the bootstrapping procedure with 5,000 replacements to assess the mediating effects (Hair et al., 2017). Besides, the assessment of mediating effects required an examination of the indirect effect of the significance levels and confidence intervals. More specifically, the mediating effects were established when the indirect effect was significant, and the confidence interval of this path excluded zero (Preacher and Hayes, 2008).

The results demonstrated a significant relationship between the market's orientation and the prospector strategy $(a=0.263$, $p=0.001)$ as well as this type of strategy and the performance of small business- 
es $(b=0.228, p=0.005)$. Besides, the results showed that the indirect effect (MO - > PS -> PER) was significant $\left(\mathrm{a}^{*} \mathrm{~b}=0.060, p=0.033\right)$. Moreover, its confidence interval was in the range $[0.017 ; 0.125]$, which does not include zero. Hence, it confirms the mediating effects of the prospector strategy on the link between market orientation and small businesses' performance.

Moreover, the type of mediation was also assessed (see Boyd et al., 2012). The results also revealed the insignificant direct path between the prospector strategy and the performance of small businesses $(c=0.174$, small businesses in Vietnam. First, the findings show the positive association between market orientation and the prospector strategy. It can be interpreted that when small businesses in Vietnam are oriented toward the market, they choose the prospector strategy as their primary strategy. One reason is that market orientation allows an insight into both the customers and competitors (Kohli and Jaworski, 1990). To gain a competitive advantage, innovation allows the delivery of new or existing products/services, which satisfy the customers' demands. In addition, when they have an insight into competitors, innovation also allows

$\mathrm{a}^{*} \mathrm{~b}=0.060^{*}$

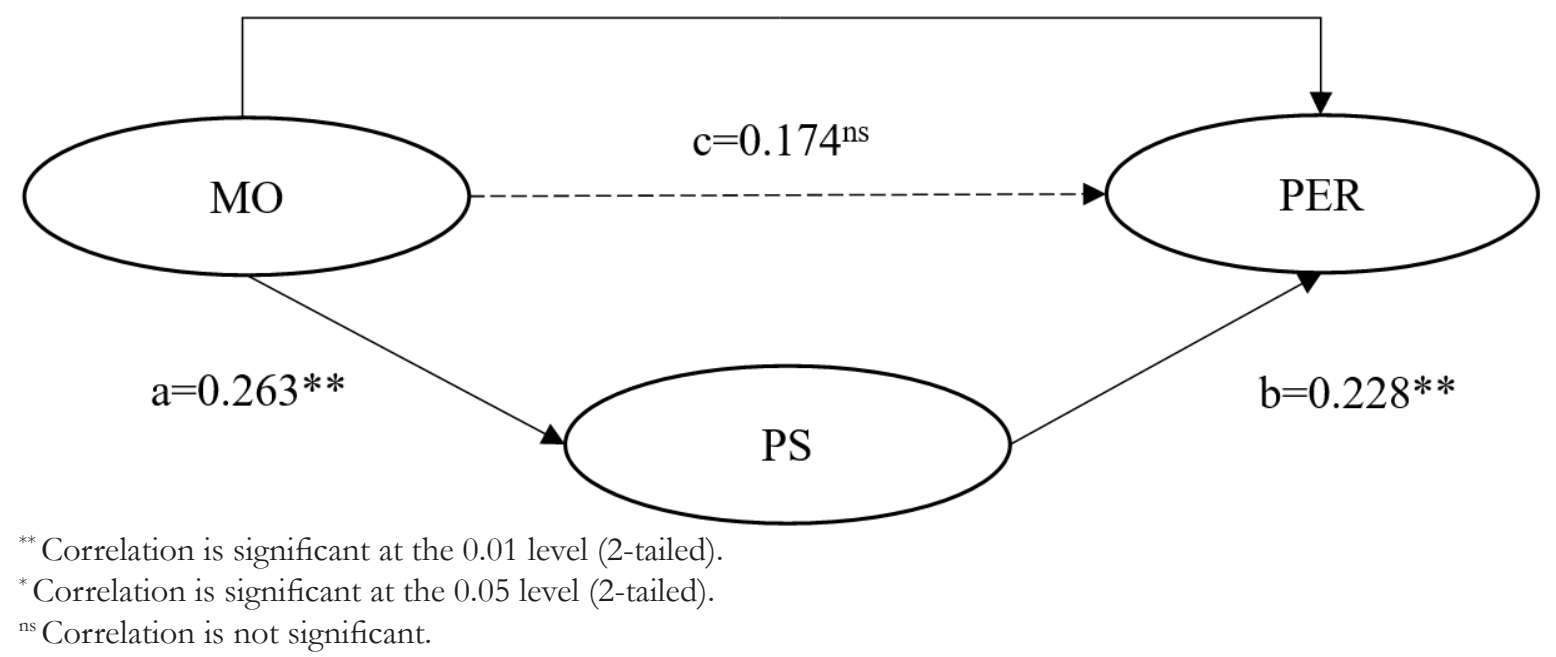

Figure 2. Results of Structural Model

$p=0.074)$ when controlling for paths $\mathrm{a}$ and $\mathrm{b}$. Hence, it supported the full mediating effects of the prospector strategy. Thus, Hypothesis H4 was supported. The full mediation represented the form of the fits between market orientation and the prospector strategy.

\section{Discussion}

The results cast light on how strategic fits between market orientation and the prospector strategy lead to higher performance by the development of new products/services ahead of those of the competitors, which gives first-mover advantages. In this regard, competitive advantages are enhanced through innovation when there is an insight into customers, and competitors resulted from the market's orientation. Selecting the prospector strategy allows small businesses to gain competitive advantages through innovation (Kickul and Gundry, 2002). Thus, they select the prospector strategy, which allows them to 
find competitive advantages through innovation when they adapt to the market's orientation. This study's results are in line with McManus (2013), who showed the significant relationship between market orientation and the prospector strategy.

Second, the findings suggest the positive correlation between the prospector strategy and small businesses' performance in Vietnam. It implies that small businesses which choose to follow the prospector strategy improve their attainment of the following targets and goals: return on investment; margin on sales; customer satisfaction; quality of the products/services; the introduction of new products/services. One proper explanation can be found in the strategic management literature. As Miles and Snow (1978) argued, prospectors perform better because they emphasize new market places. Rather than competing with their rivals by defending their market or reacting to the rivals' behavior, prospectors actively search for new ways to satisfy their customers' needs. One advantage of this strategy allows prospectors to become the first-movers in the industry (Slater and Narver, 1993), which, in turn, means they achieve high performance (Lieberman and Montgomery, 1988). The findings are consistent with previous studies. Moore (2005) and Naranjo-Gil (2004) revealed that organizations which follow the prospector strategy find performance improvements.

Third, the results reveal the insignificant relationship between market orientation and performance while controlling for the prospector strategy. It suggests that small businesses which follow a market-oriented approach do not directly achieve higher performance. The marketing literature provides some insights into this issue. More specifically, Ngo and O'Cass (2012) argued that al- though the market's orientation is crucial for organizations, it is less likely to improve their performance greatly. Consistently, Morgan et al., (2009) also argued that market orientation needs to compliment the organizational characteristics (e.g., capabilities) to induce improved performance if the organizations are to fully realize the potential of this variable. Thus, it is argued that this relationship is contingent (Kiessling et al., 2016). Kajalo and Lindblom (2015) supported this argument by showing that there is an insignificant direct relationship between these two variables, while controlling for marketing's capabilities.

Fourth, the results indicate a full mediating effect by the prospector strategy on the relationship between the market's orientation and the performance of small businesses. It suggests that the prospector strategy is the critical mediator in the link between both of them. It implies that only small businesses which choose the prospector strategy and orient themselves toward the market, find superior performance. High market orientation drives these businesses to emphasize innovation (Kohli and Jaworski, 1990). When focusing on innovation, the prospector strategy is an appropriate choice because Kickul and Gundry (2002) suggested that this strategy has a high degree of innovation. As a result, the fit between market orientation and the prospector strategy allows small businesses in Vietnam to attain their targeted goals relating to their return on investment, margin on sales, customer satisfaction, quality of the products/services, and the introduction of new products/services.

Regarding the mediating effects of strategic choices, the results are also similar to previous strategic management studies. For example, Edelman et al., (2005) found that a quality/customer service strategy is a me- 
diator between two contingency factors like human and organizational resources and firm performance. In a similar vein, Chow et al., (2013) demonstrated that the differentiation strategy mediates the relationship between human resource management systems and firm performance.

This study also provides some practical implications for the owners of small businesses in Can Tho, Vietnam. In particular, market orientation is a culture that drives small businesses to focus on identifying their customers' needs (Kohli and Jaworski, 1990). A high degree of market orientation allows these businesses to gain insights into the customers' needs and provide their products/ services to satisfy those needs, which leads to performance improvements. However, the owners should be cautious that market orientation alone cannot lead to performance improvements. Instead, the owners should choose the prospector strategy to fit with the market's orientation. The selection of the prospector strategy requires businesses to emphasize high levels of innovation to continuously search for new markets. This allows these businesses to provide products or services to meet customers' needs by enhancing the customers' experience of their products and services (Miles and Snow, 1978). A consequence of the correct fits allows businesses to perform better.

\section{Conclusion}

This study aims to get insights into how the fit between the market's orientation and the prospector strategy allows small businesses in Vietnam to improve their performance. This study shows that the orientation of the market drives these businesses to follow the prospector strategy, and in turn, this strategy allows performance improvements.
Besides, the market's orientation by itself cannot directly improve the performance of small businesses. Instead, the fit between the market's orientation and the prospector strategy induces improved performance in small businesses, to the extent that the prospector strategy acts as the mediator between market orientation and performance.

Future research can benefit from this study by extending its results. First, future studies should assess the fit between market orientation and the differentiation strategy. It is argued that this strategy shares many similarities with the prospector strategy (Miller and Friesen, 1986). By doing so, future studies can enrich the understanding of the role of the market's orientation in strategic management research. Second, future studies can also replicate this research model to other types of businesses, such as large businesses, to examine this research model's relevance in other research contexts.

\section{Limitation}

The results of this study are subject to some caveats. First, the interpretation of this study must be done cautiously if it is to be generalized to other areas in Vietnam. Because the data are collected only in Can Tho, it may be a generalization issue. However, it is not of much concern because the purpose of this study is to test the theory rather than generalize the results to larger populations. Second, this study did not perform a pilot test. Thus, it may cause noise in the questionnaire because all the measures were translated from English to Vietnamese. However, this study believes this issue is a minor one because the 
Gadjah Mada International Journal of Business - January-April, Vol. 23, No. 1, 2021

questionnaire was examined by the person

who assisted with the data's collection before

sending it to the targeted respondents. This person has a strong, practical knowledge. Lastly, the low response rate is also a limitation on this study.

\section{References}

Acquaah, M. (2007). Managerial social capital, strategic orientation, and organizational performance in an emerging economy. Strategic management journal, 28(12), 1235-1255.

Appiah-Adu, K. (1998). Market orientation and performance: do the findings established in large firms hold in the small business sector? Journal of Euromarketing, 6(3), 1-26.

Appiah-Adu, K., \& Blankson, C. (1998). Business strategy, organizational culture, and market orientation. Thunderbird International Business Review, 40(3), 235-256.

Aragón-Sánchez, A., \& Sánchez-Marín, G. (2005). Strategic orientation, management characteristics, and performance: A study of Spanish SMEs. Journal of small business management, 43(3), 287-308.

Bamfo, B. A., \& Kraa, J. J. (2019). Market orientation and performance of small and medium enterprises in Ghana: The mediating role of innovation. Cogent Business \& Management, 6(1), 1605703.

Barney, J. (1991). Firm resources and sustained competitive advantage. Journal of management, 17(1), 99-120.

Boyd, B. K., Takacs Haynes, K., Hitt, M. A., Bergh, D. D., \& Ketchen Jr, D. J. (2012). Contingency hypotheses in strategic management research: Use, disuse, or misuse? Journal of management, 38(1), 278-313.

Cadez, S., \& Guilding, C. (2008). An exploratory investigation of an integrated contingency model of strategic management accounting. Accounting, organizations and society, 33(7-8), 836-863.

Cadez, S., \& Guilding, C. (2012). Strategy, strategic management accounting and performance: a configurational analysis. Industrial Management \& Data Systems, 112(3), 484-501.

Cassel, C., Hackl, P., \& Westlund, A. H. (1999). Robustness of partial least-squares method for estimating latent variable quality structures. Journal of applied statistics, 26(4), 435-446.

Chandler, A. D. (1962). Strategy and structure: chapters in the history of American industrial enterprises. Cambridge. hlass.: MIT Press, 14, 16.

Chen, Z., Huang, S., Liu, C., Min, M., \& Zhou, L. (2018). Fit between organizational culture and innovation strategy: Implications for innovation performance. Sustainability, 10(10), 3378.

Chin, W. W. (1998). The partial least squares approach to structural equation modeling. Modern methods for business research, 295(2), 295-336.

Chow, I. H.-s., Teo, S. T., \& Chew, I. K. (2013). HRM systems and firm performance: The mediation role of strategic orientation. Asia Pacific Journal of Management, 30(1), 53-72.

Chung, H. F., Wang, C. L., \& Huang, P. h. (2012). A contingency approach to international marketing strategy and decision-making structure among exporting firms. International Marketing Review, 29(1), 54-87. 
Cravens, K. S., \& Guilding, C. (1999). Examining brand valuation from a management accounting perspective. Advances in Management Accounting, 8, 113-138.

Dierickx, I., \& Cool, K. (1989). Asset stock accumulation and sustainability of competitive advantage. Management science, 35(12), 1504-1511.

Domi, S., Capelleras, J.-L., \& Musabelliu, B. (2020). Customer orientation and SME performance in Albania: A case study of the mediating role of innovativeness and innovation behavior. Journal of Vacation Marketing, 26(1), 130-146.

Donaldson, L. (2001). The contingency theory of organizations: Sage.

Ebben, J. J., \& Johnson, A. C. (2005). Efficiency, flexibility, or both? Evidence linking strategy to performance in small firms. Strategic management journal, 26(13), 1249-1259.

Edelman, L. F., Brush, C. G., \& Manolova, T. (2005). Co-alignment in the resource-performance relationship: strategy as mediator. Journal of Business Venturing, 20(3), 359-383.

Fabrigar, L. R., Wegener, D. T., MacCallum, R. C., \& Strahan, E. J. (1999). Evaluating the use of exploratory factor analysis in psychological research. Psychological methods, 4(3), 272.

Fornell, C., \& Larcker, D. F. (1981). Evaluating structural equation models with unobservable variables and measurement error. Journal of marketing research, 18(1), 39-50.

Galbraith, J. R., \& Nathanson, D. A. (1978). Strategy implementation: The role of structure and process: West Pub. Co.

Gaur, S. S., Vasudevan, H., \& Gaur, A. S. (2011). Market orientation and manufacturing performance of Indian SMEs. European Journal of Marketing, 45(7/8), 1172-1193.

Geisser, S. (1974). A predictive approach to the random effect model. Biometrika, 61(1), 101-107.

Gimenez, F. A. (2000). The benefits of a coherent strategy for innovation and corporate change: a study applying Miles and Snow's model in the context of small firms. Creativity and innovation management, 9(4), 235-244.

Grimmer, L., Grimmer, M., \& Mortimer, G. (2018). The more things change the more they stay the same: A replicated study of small retail firm resources. Journal of Retailing and Consumer Services, 44, 54-63.

Gruber-Muecke, T., \& Hofer, K. M. (2015). Market orientation, entrepreneurial orientation and performance in emerging markets. International Journal of Emerging Markets, 10(3), 560-571.

Guidelines for Law on Support for Small and Medium-Sized Enterprises, 39/2018/ND-CP C.F.R. (2018).

Guilding, C., \& McManus, L. (2002). The incidence, perceived merit and antecedents of customer accounting: an exploratory note. Accounting, organizations and society, 27(1-2), 45-59.

Hair, J. F., Hult, G. T. M., Ringle, C. M., Sarstedt, M., \& Thiele, K. O. (2017). Mirror, mirror on the wall: a comparative evaluation of composite-based structural equation modeling methods. Journal of the Academy of Marketing Science, 45(5), 616-632.

Hair, J. F., Ringle, C. M., \& Sarstedt, M. (2011). PLS-SEM: Indeed a silver bullet. Journal of Marketing theory and Practice, 19(2), 139-152.

Hair, J. F., Sarstedt, M., Pieper, T. M., \& Ringle, C. M. (2012). The use of partial least squares structural equation modeling in strategic management research: a review of past practices and recommendations for future applications. Long range planning, 45(5-6), 320-340.

Henseler, J., Ringle, C. M., \& Sarstedt, M. (2015). A new criterion for assessing discriminant validity in variance-based structural equation modeling. Journal of the Academy of Marketing 
Gadjah Mada International Journal of Business - January-April, Vol. 23, No. 1, 2021

Science, 43(1), 115-135.

Hitt, M. A., Boyd, B. K., \& Li, D. (2004). The state of strategic management research and a vision of the future. Research methodology in strategy and management, 1, 1-31.

Ibrahim, A. B. (1993). Strategy types and small firms' performance an empirical investigation. Journal of Small Business Strategy, 4(1), 13-22.

Jarvis, R., Curran, J., Kitching, J., \& Lightfoot, G. (2000). The use of quantitative and qualitative criteria in the measurement of performance in small firms. Journal of small business and enterprise development, 7(2), 123-134.

Kajalo, S., \& Lindblom, A. (2015). Market orientation, entrepreneurial orientation and business performance among small retailers. International Journal of Retail \& Distribution Management, 43(7), 580-596.

Kald, M., Nilsson, F., \& Rapp, B. (2000). On strategy and management control: the importance of classifying the strategy of the business. British Journal of Management, 11(3), 197-212.

Kickul, J., \& Gundry, L. (2002). Prospecting for strategic advantage: The proactive entrepreneurial personality and small firm innovation. Journal of small business management, 40(2), 85-97.

Kiessling, T., Isaksson, L., \& Yasar, B. (2016). Market orientation and CSR: Performance implications. Journal of Business Ethics, 137(2), 269-284.

Kohli, A. K., \& Jaworski, B. J. (1990). Market orientation: the construct, research propositions, and managerial implications. Journal of marketing, 54(2), 1-18.

Koushan, D. (2017). Facilitating SME Growth in Vietnam. https://www.vietnam-briefing.com/ news/facilitating-sme-growth-vietnam.html/.

Leal-Rodríguez, A. L., \& Albort-Morant, G. (2016). Linking market orientation, innovation and performance: An empirical study on small industrial enterprises in Spain. Journal of Small Business Strategy, 26(1), 37-50.

Lieberman, M. B., \& Montgomery, D. B. (1988). First-mover advantages. Strategic management journal, 9(S1), 41-58.

Lim, J.-S., Darley, W. K., \& Marion, D. (2017). Market orientation, innovation commercialization capability and firm performance relationships: the moderating role of supply chain influence. Journal of Business \& Industrial Marketing, 32(7), 913-924.

Lindell, M. K., \& Whitney, D. J. (2001). Accounting for common method variance in cross-sectional research designs. Journal of Applied Psychology, 86(1), 114.

Lowe, J., \& Atkins, M. (1994). Small firms and the strategy of the first mover. International Journal of the Economics of Business, 1(3), 405-419.

Mateos-Aparicio, G. (2011). Partial least squares (PLS) methods: Origins, evolution, and application to social sciences. Communications in Statistics-Theory and Methods, 40(13), 2305-2317.

McManus, L. (2013). Customer accounting and marketing performance measures in the hotel industry: Evidence from Australia. International Journal of Hospitality Management, 33, 140 152.

Migliori, S., Pittino, D., Consorti, A., \& Lucianetti, L. (2019). The relationship between entrepreneurial orientation, market orientation and performance in university spin-offs. International Entrepreneurship and Management Journal, 15(3), 793-814.

Miles, R. E., \& Snow, C. C. (1978). Organizational strategy, structure, and process (Vol. 3). London: McGraw Hill. 
Miller, D., \& Friesen, P. H. (1986). Porter's (1980) Generic Strategies and Performance: An Empirical Examination with American Data: Part II: Performance Implications. Organization studies, 7(3), 255-261.

Moore, M. (2005). Towards a confirmatory model of retail strategy types: an empirical test of Miles and Snow. Journal of Business Research, 58(5), 696-704.

Morgan, N. A., Vorhies, D. W., \& Mason, C. H. (2009). Market orientation, marketing capabilities, and firm performance. Strategic management journal, 30(8), 909-920.

Naranjo-Gil, D. (2004). The role of sophisticated accounting system in strategy management. International Journal of Digital Accounting Research, 4(8), 125-144.

Narver, J. C., \& Slater, S. F. (1990). The effect of a market orientation on business profitability. Journal of marketing, 54(4), 20-35.

Newman, A., Prajogo, D., \& Atherton, A. (2016). The influence of market orientation on innovation strategies. Journal of service theory and practice.

Ngo, L. V., \& O’Cass, A. (2012). Performance implications of market orientation, marketing resources, and marketing capabilities. Journal of Marketing Management, 28(1-2), 173-187.

Nooteboom, B. (1994). Innovation and diffusion in small firms: theory and evidence. Small business economics, 6(5), 327-347.

O’Dwyer, M., \& Gilmore, A. (2019). Competitor orientation in successful SMEs: An exploration of the impact on innovation. Journal of strategic marketing, 27(1), 21-37.

Ozkaya, H. E., Droge, C., Hult, G. T. M., Calantone, R., \& Ozkaya, E. (2015). Market orientation, knowledge competence, and innovation. International Journal of Research in Marketing, 32(3), 309-318.

Parnell, J. A. (2013). Uncertainty, generic strategy, strategic clarity, and performance of retail SMEs in Peru, Argentina, and the United States. Journal of small business management, 51(2), 215-234.

Penrose, E., \& Penrose, E. T. (2009). The Theory of the Growth of the Firm: Oxford university press.

Pertusa-Ortega, E. M., Molina-Azorín, J. F., \& Claver-Cortés, E. (2010). Competitive strategy, structure and firm performance. Management Decision, 48(8), 1282-1303.

Podsakoff, P. M., \& Organ, D. W. (1986). Self-reports in organizational research: Problems and prospects. Journal of management, 12(4), 531-544.

Preacher, K. J., \& Hayes, A. F. (2008). Asymptotic and resampling strategies for assessing and comparing indirect effects in multiple mediator models. Behavior research methods, 40(3), 879-891.

Raymond, L., \& St-Pierre, J. (2013). Strategic capability configurations for the internationalization of SMEs: A study in equifinality. International Small Business Journal, 31(1), 82-102.

Singh, S., \& Ranchhod, A. (2004). Market orientation and customer satisfaction: Evidence from British machine tool industry. Industrial Marketing Management, 33(2), 135-144.

Slater, S. F., \& Narver, J. C. (1993). Product-market strategy and performance: an analysis of the Miles and Snow strategy types. European Journal of Marketing, 27(10), 33-51.

Slater, S. F., \& Narver, J. C. (1994a). Does competitive environment moderate the market orientation-performance relationship? Journal of marketing, 58(1), 46-55.

Slater, S. F., \& Narver, J. C. (1994b). Market orientation, customer value, and superior performance. Business horizons, 37(2), 22-28. 
Gadjah Mada International Journal of Business - January-April, Vol. 23, No. 1, 2021

Song, L., Augustine, D., \& Yang, J. Y. (2016). Environmental uncertainty, prospector strategy, and new venture performance: the moderating role of network capabilities. International Entrepreneurship and Management Journal, 12(4), 1103-1126.

Speklé, R. F., \& Widener, S. K. (2018). Challenging issues in survey research: Discussion and suggestions. Journal of Management Accounting Research, 30(2), 3-21.

Stone, M. (1974). Cross-validatory choice and assessment of statistical predictions. Journal of the Royal Statistical Society: Series B (Methodological), 36(2), 111-133.

Taylor, A., \& Taylor, M. (2014). Factors influencing effective implementation of performance measurement systems in small and medium-sized enterprises and large firms: a perspective from Contingency Theory. International Journal of Production Research, 52(3), 847-866.

Tsiotsou, R. H., \& Vlachopoulou, M. (2011). Understanding the effects of market orientation and e-marketing on service performance. Marketing Intelligence \& Planning, 29(2), 141-155.

Vega-Vázquez, M., Cossío-Silva, F.-J., \& Revilla-Camacho, M.-Á. (2016). Entrepreneurial orientation-hotel performance: Has market orientation anything to say? Journal of Business Research, 69(11), 5089-5094.

Venkatraman, N. (1989). The concept of fit in strategy research: Toward verbal and statistical correspondence. Academy of Management Review, 14(3), 423-444.

Venkatraman, N., \& Camillus, J. C. (1984). Exploring the concept of "fit" in strategic management. Academy of Management Review, 9(3), 513-525.

Wernerfelt, B. (1984). A resource-based view of the firm. Strategic management journal, 5(2), 171180.

Wu, T., Wu, Y.-C. J., Chen, Y. J., \& Goh, M. (2014). Aligning supply chain strategy with corporate environmental strategy: A contingency approach. International Journal of Production Economics, 147, 220-229.

Yadav, S. K., Tripathi, V., \& Goel, G. (2019). Mediating effect of innovation with market orientation and performance relationship. Management Research: Journal of the Iberoamerican Academy of Management, 17(2), 152-167.

Yarbrough, L., Morgan, N. A., \& Vorhies, D. W. (2011). The impact of product market strategy-organizational culture fit on business performance. Journal of the Academy of Marketing Science, 39(4), 555-573.

Zhao, X., Lynch Jr, J. G., \& Chen, Q. (2010). Reconsidering Baron and Kenny: Myths and truths about mediation analysis. Journal of consumer research, 37(2), 197-206. 
Appendix

\begin{tabular}{lllll}
\hline Market Orientation (MO) & 1 & 2 & 3 & 4 \\
$\begin{array}{l}\text { Please indicate the degree to which you agree with the } \\
\text { following statements. }\end{array}$ & $\begin{array}{l}\text { Highly } \\
\text { Disagree }\end{array}$ & Neutral & $\begin{array}{l}\text { Highly } \\
\text { Agree }\end{array}$ \\
\hline
\end{tabular}

1. My business has a strong understanding of our customers.

2. The functions in my business work closely together to create superior value for our customers.

3. Management in my business thinks in terms of serving the needs and wants of well-defined markets chosen for their long-term growth and profit potential for the company

4. My business has a strong market orientation.

\begin{tabular}{lllll}
\hline Prospector Strategy (PS) & 1 & 2 & 3 & 4 \\
$\begin{array}{l}\text { Please indicate the degree to which you agree with the } \\
\text { following statements regarding your business's behaviors. }\end{array}$ & $\begin{array}{l}\text { Highly } \\
\text { Disagree }\end{array}$ & & Neutral & Highly \\
\hline
\end{tabular}

1. My business is an innovation leader in the industry.

2. My business frequently moves into new markets.

3. My business is known for being "first in" the industry for developing new ways to perform.

4. My business does not mind risking profits when developing new products/services.

5. My business is a leader in developing new ways to perform.

6. My business continuously adopts new technology.

\begin{tabular}{|c|c|c|c|c|c|}
\hline Performance of Small Businesses (PER) & 1 & 2 & 3 & 4 & 5 \\
\hline $\begin{array}{l}\text { Please indicate your business's performance and the ex- } \\
\text { tent to which your business attains the following targeted } \\
\text { goals. }\end{array}$ & $\begin{array}{l}\text { Well Below } \\
\text { Average }\end{array}$ & & Average & & $\begin{array}{l}\text { Well Above } \\
\text { Average }\end{array}$ \\
\hline
\end{tabular}

1. Return on investment.

2. Margin on sales.

3. Capacity utilization.

4. Customer satisfaction.

5. Product/service quality.

6. Introduction of new products/services.

\begin{tabular}{lllll}
\hline Marker Variable (MV) & 1 & 2 & 3 & 4 \\
$\begin{array}{l}\text { Please indicate the degree to which you agree with the } \\
\text { following statements. }\end{array}$ & $\begin{array}{l}\text { Highly } \\
\text { Disagree }\end{array}$ & & Neutral & $\begin{array}{l}\text { Highly } \\
\text { Agree }\end{array}$ \\
\hline
\end{tabular}

1. Travelling is important.

2. Travelling is necessary.

3. Travelling is beneficial. 